Zaika S. O., Ph.D., Associate Professor
Kuskova S. V., Ph.D., Associate Professor

Zaika O. V., Assistant Lecturer

Kharkiv Petro Vasylenko National Technical University of Agriculture

Kharkiv, Ukraine

DOI: https://doi.org/10.30525/978-9934-26-064-3-22

\title{
FEATURES OF MARKETING COMMUNICATIONS ON THE INTERNET
}

The effective functioning of the enterprise at this stage of economic development is impossible to imagine without the use of mechanisms for organizing marketing activities. There are many different types of marketing, among them are such as conversion, incentive, development, support and more. The rapid development of the market of goods and services changes the desire of consumers, forcing manufacturers to seek new methods of promotion and sale of manufactured products, as changing consumer tastes leads to a decline in the effectiveness of marketing techniques that have been used for a long time. Due to the development of communication and information technologies, such type of marketing as Internet marketing is becoming more and more popular [7].

Internet marketing is significantly different from conventional marketing communications through the use of virtual information space. The Internet and other digital media are opening up new forms of interaction and new models of information exchange.

The high interactivity of the Internet as an information environment is due to the following facts:

- the client initiates the contact himself;

- the customer himself is looking for information about brands and products;

- the use of the Internet requires the involvement of a person, unlike radio or television, which can be listened to and watched in the background. 
The main function of traditional marketing is to motivate the consumer to take targeted action through the broadcast of the advertising message from the company to the client and other stakeholders, i.e. in this case the PUSH approach is used. At the same time, interaction with clients is significantly limited; additional research and surveys are often needed to get feedback.

The same thing happens on the Internet, especially when using email and media advertising, but customers can initiate contact themselves when searching for information on websites and search engines. In other words, there is a PULL approach, so it is very important to have good visibility in search engines $[1 ; 3]$.

D. Hoffman and T. Novak expressed the opinion that digital media has changed the model of communication. According to them, the Internet is a computer-mediated environment in which interactions occur not only between the sender and recipient of information, but also with the environment itself [2].

It should also be noted that, unlike television, radio and print media, the Internet allows you to post free videos and audio recordings of any length, use surveys, initiate discussions between people, create interactive games and programs.

The Internet can be used as a relatively inexpensive way to conduct marketing research using CAPI technology (Computer-assisted personal interviewing - a personal interview using a computer).

The second channel for receiving information about customers is the company's website, if it has a web analytics system. Many Internet marketers use this data to study the preferences and behavior of consumers depending on how the information is organized and what graphic elements are used on the site.

Internet marketing communications can be adapted to each individual or consumer segment.

Unlike traditional media, where in most cases one message is broadcast to the entire audience, in Internet marketing at relatively low cost there is the possibility of individual treatment of each individual consumer segment. 
In recent years, a new technology of retargeting is developing rapidly - advertising and informational messages are shown only to those users who have already visited the site and made certain actions there. In particular, this technology allows you to return to the site consumers who have studied certain products, showing them on various third-party web resources and social networks advertising with their product or service, encouraging them to make a purchase by offering a personal discount, gift or bonus.

The Internet has significantly changed the essence of intermediary relations in business. For a marketer who develops a communication strategy for his company on the Internet, it is very important to consider how the brand can be represented on the websites of intermediaries and what intermediaries are generally needed to ensure distribution on the Internet.

It is also worth noting that electronic means of communication have expanded the coverage of advertising campaigns for Internet users in all countries. This enabled any company to sell goods and provide services in the international market, which was previously only available to large corporations [7].

At the same time, of course, there are some difficulties in implementing Internet marketing. After all, in addition to the fact that Internet marketing requires an understanding of the tools, methodology and other aspects of traditional marketing, much attention is also paid to the study of ever-changing network technologies, new web services and promotion tools.

Based on the considered features of Internet marketing, a table was compiled showing its main advantages and disadvantages for companies that plan to use it or already use it (Table 1).

Despite its shortcomings, Internet marketing is able to provide a competitive advantage to firms that systematically use it in the market.

Thus, Internet marketing today is one of the most promising areas of marketing in our country. This area is actively developing, despite economic crises and various external and internal obstacles. It is also worth noting that Internet marketing, like any type of marketing has 
its advantages and disadvantages, which must be considered when using its tools in the implementation of the enterprise.

Table 1

Advantages and disadvantages of Internet marketing

\begin{tabular}{|l|l|}
\hline \multicolumn{1}{|c|}{ Advantages } & \multicolumn{1}{c|}{ Disadvantages } \\
\hline - Low cost when working with narrow & \\
segments of consumers & - Relatively high cost when \\
- High coverage of the most economically & working with a mass audience \\
active audience & - Low audience coverage of \\
- High interactivity of interaction & older age groups \\
- Extensive opportunities for orientation & - Technological limitations \\
- Personalization of communication & - Information overload of users \\
- Great opportunities for consumer research & - Small e-commerce turnovers \\
and analysis of the effectiveness of & - The complexity of planning \\
advertising activity & and implementing Internet \\
- Relatively high average level of trust in & marketing \\
Internet advertising & \\
\hline
\end{tabular}

Source: [1-7]

Internet marketing allows you to reduce the cost of sales, expand the market by reaching new audiences, the use of modern methods of advertising, also allows you to analyze the demand for goods, which provides the ability to adjust and meet market requirements, but with the development of Internet technologies, you also need to develop a sales system, take into account the possibility of failure of the site, which will store information about the goods.

\section{References:}

1. Chaffey D. (2006) Internet Marketing: Strategy, Implementation and Practice / F.Ellis-Chadwick, R. Mayer, K. Johnston. Pearson Education, p. 579.

2. Hoffman D., Novak T. Marketing in Hypermedia Computer-Mediated Environments. URL: http://citeseerx.ist./viewdoc/download?doi=10.197.3580= rep1\&type $=$ pdf

3. Kvyatko T., Zaika S. (2020) Benchmarking as an element of marketing activities of ukrainian enterprises. Modern scientific and technical methods of management information flow and their influence on the development of society. Abstracts of V International Scientific and Practical Conference. Frankfurt am Main, Germany, p. 12-14. URL: http://isg-conf.com 
4. Kvyatko T., Zaika S., Gridin A. (2020) The impact of marketing on agricultural business development. The 6 th International scientific and practical conference «Perspective directions of science and practice» (02-03 March, 2020). Athers, Greece, pp. 257-259.

5. Zaika S.O., Kuskova S.V. (2020) Sutnist marketynhovoi kontseptsii upravlinnia tovarnoiu politykoiu pidpryiemstva [The essence of the marketing concept of product policy management of the enterprise]. Materialy Mizhnarodnoi naukovopraktychnoi konferentsii «Suchasnyi marketynh: stratehichne upravlinnia ta innovatsiinyi rozvytok»: do 90-richchia zasnuvannia KhNTUSH [Proceedings of the International Scientific and Practical Conference «Modern Marketing: Strategic Management and Innovative Development»: to the 90th anniversary of the KhNTUA], April 30, 2020. Kharkiv, KhNTUA, p. 95-96.

6. Kozhukhivska R.B. (2012) Internet-tekhnolohii v marketynhu: spetsyfika, klasyfikatsiia, perevahy ta nedoliky [Internet-tekhnolohii v marketynhu: spetsyfika, klasyfikatsiia, perevahy ta nedoliky]. Bulletin of Dnipropetrovsk University. Economics Series, no. 10/1, vol. 20, output 6/2, pp. 180-186.

7. Kurmanov N.V. (2013) Kompleksnoye onlayn-prodvizheniye - put k liderstvu na rynke: Comprehensive online promotion - the path to market leadership. Internet Marketing, no. 4, pp. 248-259. 